\title{
Actors' Power, Livelihood Assets and Participatory Forestry in Bangladesh: Evidence from the Sal Forests Area
}

\author{
K. K. Islam1, Hyakumura Kimihiko², Masakazu Tani' ${ }^{3}$, Max Krott, Noriko Sato1 \\ ${ }^{1}$ Forest Policy Laboratory, Kyushu University, Hakozaki, Higashi, Fukuoka, Japan \\ ${ }^{2}$ Institute of Tropical Agriculture, Kyushu University, Hakozaki, Higashi, Fukuoka, Japan \\ ${ }^{3}$ Faculty of Design, Kyushu University, Shiobaru, Minami, Fukuoka, Japan \\ ${ }^{4}$ Chair of Forest and Nature Conservation Policy, Georg-August University Gottingen, Buesgenweg 3, Germany \\ Email: kamrulbau@gmail.com
}

Received August 2014

\section{Abstract}

Decentralize in forest management policies towards more people-oriented approaches has become major policy trends in many of the world's developing countries during the last decade. However, the power of important actors to misuse the participatory forestry (PF) approach for their self-interests has been stated as a main problem to success. So, this study attempted to identify the most powerful actors and the extent at which they influence the outcomes of PF, and also to measure the impact of PF on livelihood assets of participants. The empirical data were collected from the well-established PF programs at Madhupur Sal forests area of Bangladesh. The results showed that the forest department (FD) proved itself as the most powerful and influential actor in every element of power analysis in PF. Regarding to livelihood analysis, the results revealed that the overall value of participants' livelihood assets was 0.85 and it was significantly differed from the non-participants value of 0.66 . However, the development of human, physical and financial assets was not indicating a decent improvement like as natural and social assets of participants. So, it is necessary to pay more attention to boost up participants' human and financial assets through intensive training and adopting proper tree-crop production techniques, and also ensuring alternative livelihoods approaches to the local people. In addition, the local government will need to pay more emphasis on constructing village roads and infrastructure so as to enhance physical assets of the local people. Finally, the study would recommend promoting PF with apposite government facilities and also empowering local participants in order to balance the power among different actors, and this will facilitate the participants in governing all of their development activities efficiently.

\section{Keywords}

Participatory Forestry, Actor, Power, Livelihood Assets, Sal Forests, Bangladesh 


\section{Introduction}

Forest resources and its management are increasingly observed to play a role in rural development, providing the resources necessary to drive local poor livelihoods improvement and poverty alleviation strategies (Islam \& Sato, 2012a; Islam et al., 2012, 2013). So, the decentralization of traditional forest management strategies towards more people-oriented approaches have become popular in many of the world's developing countries in recent decades (Brown, 2009). The experiences of people-oriented forest management throughout the world have evidence that decentralize and devolution policies yield benefits for local people, but in realities there are also lots of limiting factors (Larson \& Ribot, 2007; Ribot, 2004). Moreover, this approach is characterized by many actors due to the economic, ecological and social functions and values that forests delivers. Besides the local communities, other groups at regional, national and international levels also have an impact on local communities' access to forests (Peluso et al., 1994). However, all actors are important in forest management and their cooperation are needed for sustainable forest management; often the state showed the most dominant and strong role over other actors (Krott, 2005; Devkota, 2010; Barrow et al., 2002).

Bangladesh, with a forest cover of $17.08 \%$ land surface area, has experienced severe degradation of its forest resources and a considerable change in its land cover (Islam \& Sato, 2012b; FD, 2014). It was recognized in Bangladesh that social factors affect forest degradation, and combating poverty is a prerequisite for forest resource management. Therefore, the government of Bangladesh has set utmost priority on people-oriented forest management approach starting since 1980s, and this approach (Participatory Forestry) was commenced in the degraded Sal forests areas in 1989 (Islam \& Sato, 2012a, 2012b). Sal forests are considered the most important forests in Bangladesh due its economic and ecological importance (Muhammad et al., 2008; Islam et al., 2012; Safa, 2004). However, the PF program at Sal forests area is considered as government control and donor funded project in Bangladesh. PF program has also been treated political in nature due to its contestant type of access and control over forests in social and power relations. So, the PF created an emblematic struggle between various kinds of actors in term of dominance and power relations. Nevertheless, power has played a progressively important role in forest policy analysis since the execution of PF approaches in Sal forests as well as in whole Bangladesh. So, there is an immediate need to find out the main issues relating to power, interests and outcomes in PF activities and their influence to policy cycle in Bangladesh.

Forest resources and its proper management systems have the potential to contribute positively to the improvement of rural livelihoods and poverty reduction (Brown et al., 2002; Fometer \& Vermaak, 2001). It is true in Bangladesh that the forest cover is shrinking but still a number of poor people depend on forest for their livelihoods (Islam \& Sato, 2012a). There are many forest management approaches having been launched by the government of Bangladesh in order to conserve the forest and also improve the livelihoods of poor forest dependent people. Of them, participatory forestry is a better approach that has been effective to sustain livelihood and resource conservation. PF is considered as people oriented, community based, resource focused and partnership based management approach (Chen et al., 2012; Bond et al., 2006). The evidences of PF in Bangladesh have revealed that decentralization and devolution of power among the PF actors often yield benefit to local participants (Islam \& Sato, 2012a). So, there is a strong relationship between actors power and livelihood development in PF.

Analysis of livelihood in particularly the quantitative aspect is critical and for this, most of the studies followed qualitative analysis of livelihood. Moreover, the changes of livelihood through the impact of PF are another challenges in Bangladesh due to very limited available data and previous studies. Thus, the study first identify the most powerful actors and the extent at which they influence the outcomes of PF, and secondly, to measure the impacts of PF on the livelihood assets of participants.

\section{Theoretical Frameworks}

The study has based on actor centered power and livelihood theories. Power is a social relationship where actor A alters the behavior of actor B without recognizing B's will (Maryudi, 2011). Social scientist's Webber (1964) already discussed the theory of power against resistance, and according to his discussion the power against resistance can broke hardly (called coercion) and softly (called incentives) in social relations. In addition with Webber perception there is possibility that power relation can be presented without resistance, i.e. "trust”. So, the study's elements of actor concentered power consists of coercion, incentives and trust (Webber, 1964; Maryudi, 2011) (Figure 1).

Simply trust is a power element through which the subordinate changes his behavior by accepting the poten- 


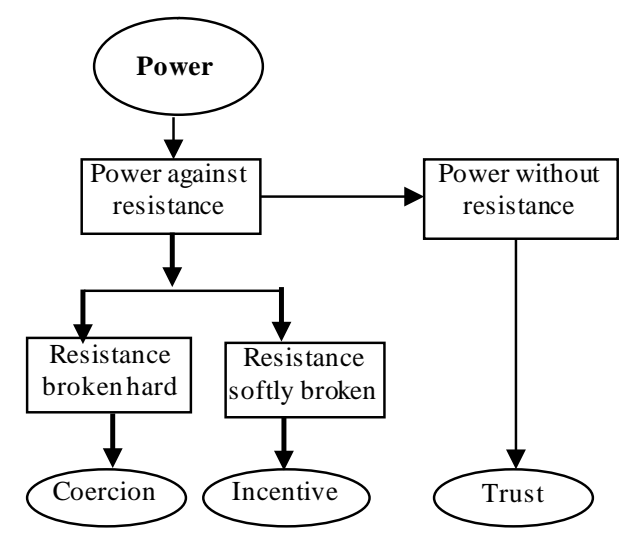

Figure 1. Elements of actor centered power.

tate's information (Devkota, 2010; Itubo, 2011). Power is exercised by use of information. The practice where an individual or a group of person is force by a different party to involuntarily behave in a certain manner is coercion. This made possible by either action or inaction (Krott, 2005; Krott et al., 2013; Itubo, 2011). However, incentives are financial or non-financial factors that alternate a subordinate's behavior by motivation. Here motivation is the initiation of goal-oriented attitude, and also the expectation of benefits that encourages people to change their behavior. So, the actor centered power conception is regarded as more useful for the analysis of power in the case of forest management and policy issues.

The study also explore the livelihood theories and the Sustainable Livelihood Analysis (SLA) framework developed by the DFID was the main basis of this study. SLA framework looks at the basic dynamics of livelihoods and how people are represented on a set of assets as a basis for their livelihoods (Carney, 1998; Hussein \& Nelson, 1998). So, SLA firsts look for identify the important assets such as physical, human, social, natural and financial related to livelihood. The livelihood assets also called livelihood capitals are represented as human capital (knowledge, skill, labor, good health), physical capital (infrastructure, transport, shelter and communication), social capital (relationship of trust and reciprocity, networks and membership of groups), natural capital (land, forests, water, wildlife and biodiversity) and financial capital (monetary resources-savings, credit and remittances). Improvements of five livelihood assets could be termed as strong SLA, whereas improvement in only some of the assets that compensate for any decline in other assets could be termed as weak or poor SLA (Islam \& Sato, 2012a). Participatory forestry is people oriented, community based, resource focused and partnership-based resources model which focused on community and emphasized natural resource management and livelihood development (Bond et al., 2006; Chen at al., 2013; Islam \& Sato, 2012a). Therefore, the study have attempt to measure livelihood assets of participants influenced by PF programs.

\section{Methodology}

\subsection{Study Area}

The moist deciduous Sal forests cover an area of 120,000 ha and these forests owned by the Bangladesh Forest Department (FD, 2014; Islam \& Sato, 2012a). Sal forests are distributed over the relatively drier central and north-western part of the country consists of mainly Tangail, Mymensingh, Gazipur and Dhaka districts. Majority of the Bangladesh Sal forests are located at the Tangail and Mymensing districts which is called Madhupur Sal forests and considered one of the most significance PF areas in Bangladesh (Islam \& Sato, 2012a; Islam et al., 2013). The study was conducted at the whole Madhupur Sal forests area of Bangladesh.

\subsection{Description of Participatory Forestry Program}

In this program, each participant (local people who is a member of participatory forestry program called Participant) was allocated 1 ha of degraded forest land for PF plantation duration of 10 year rotation cycle. Each participant can continue up to three rotation cycles (30 years) if he/she maintain the program criteria properly. The fast growing firewood producing tree species (e.g. Acacia spp., Bokain, Gamar) were selected for plantation with a spacing of $2 \mathrm{~m} \times 2 \mathrm{~m}$ (total 2500 tree/ha). After 4 years, $50 \%$ of the standing trees were thinned out $\left(1^{\text {st }}\right.$ 
thinning) and this technique was repeated after 7 years $\left(2^{\text {nd }}\right.$ thinning). The remaining 625 (approximately) trees were finally harvested at the end of the 10-year cycle. The FD and participants shared the benefit of the $2^{\text {nd }}$ thinning and final tree harvest outputs at a ratio of $45 \%: 45 \%$ and the remaining $10 \%$ benefit will store for future tree plantation called TFF (Tree Farming Fund). The participant can cultivate annual crops in association with trees at any time of the 10-year rotation cycle and the crops together with $1^{\text {st }}$ thinning benefits were granted solely to the member. This type of participatory forest management approaches were gaining popularity in all over the Bangladesh.

\subsection{Sampling, Data Collection and Analytical Techniques}

Both qualitative and quantitative data were collected to visualize the impacts of PF on participants' livelihoods assets and identify the actors' power dynamics in this study. Quantitative data were collect through a semistructured questionnaire survey, and for qualitative data this study used interview of forest department staff, local people, journalists, non-government organizations staff, leaders and donor agencies key staff. This study also conducted focus group discussion, personal observation and literature review to collect data. The study randomly selected 60 participants for interview and 30 non-participants who were possessing similar socioeconomic conditions with participant before stated PF program. A total of 3327 PF participants were involved in Madhupur Sal forests area (Islam \& Sato, 2012a). During field visit actors were asked about their views on other actors and this study tried to cover all PF actors listed in the result section. Interview questionnaire were pretested and improved before conducting the final interview and a research team consisting of 5 members were involving in data collection at Madhupur area during different months of 2012 to 2014.

For the actor power analysis, the study covered every actors and also asked each actor their judgment on the power elements of coercion, incentives and trust for the other actors. To measure the different elements of power, the study used a simple scaling systems of 2 for powerful actors and 1 for non-powerful actors (Table 1) and finally the average round numerical figure were tabulated. On the other hand, various scaling and indexing me-

Table 1. Summary of power analysis.

\begin{tabular}{|c|c|c|c|c|}
\hline \multirow{2}{*}{ Actor category } & \multicolumn{3}{|c|}{ Power elements } & \multirow{2}{*}{-Actors in the networks } \\
\hline & Trust & Incentive & Coercion & \\
\hline \multirow{3}{*}{$\begin{array}{l}\text { Forest department (local to } \\
\text { regional level) (3) }\end{array}$} & 1 & 2 & 1 & Divisional Forest Officer \\
\hline & 1 & 2 & 1 & Range Officer \\
\hline & 2 & 2 & 2 & Beat Officer \\
\hline \multirow{4}{*}{ Donor (4) } & 1 & 1 & 1 & Forestry Sector Project \\
\hline & 1 & 1 & 1 & Nishorgo Support Project \\
\hline & 1 & 1 & 1 & Upazilla Afforestation and Nursery Development Project \\
\hline & 1 & 2 & 1 & Community Forestry Project \\
\hline State ministry 1 (central level) & 2 & 1 & 1 & Ministry of Forests and Environment \\
\hline State ministry 2 (central level) & 1 & 1 & 1 & Ministry of Roads and Highway \\
\hline \multirow{2}{*}{ Forest department (central level) } & 1 & 1 & 1 & Wildlife Management and Nature Conservation Division \\
\hline & 2 & 1 & 1 & Madhupur National Park Management \\
\hline \multirow{2}{*}{ Private sector } & 1 & 1 & 1 & Saw miller \\
\hline & 1 & 1 & 1 & Brick field \\
\hline \multirow{2}{*}{ Leader } & 1 & 1 & 1 & Local Political Leader \\
\hline & & & & Union Parishad Leader \\
\hline Social forest association & 1 & 1 & 2 & Local Social Forest Committee \\
\hline Development organizations & 1 & 2 & 1 & BRAC, Christian Missionary \\
\hline Individual & 1 & 1 & 1 & Encroacher \\
\hline State ministry & 1 & 1 & 1 & Bangladesh Air Force \\
\hline Print media & 1 & 1 & 1 & Journalist \\
\hline
\end{tabular}


thods was adopted to measure human, physical, social, natural and financial capitals so that it was possible to make them comparable and to allow meaningful interpretation. Most of the indicators are determined by using rating scale methods in terms of different weight: 0.33, 0.66 and 1.0 interpreted as poor, medium/average and good. The questions that have three answer choices measured as: I $=$ Good $\% \times 1+$ Medium $\% \times 0.66+$ Poor $\% \times$ 0.33 . The two answer questions, Yes or No were interpreted as: $\mathrm{I}=\mathrm{Yes} \% \times 1+\mathrm{No} \% \times 0$. The economic benefit questions related to money was measured in different ways. Less than the mean value was classified as poor with the weight of 0.33 ; more than the mean but less than $1.5 \times$ mean treated as medium/average with the weight of 0.66; and more than $1.5 \times$ mean was classified as good with the weight of 1.0. Similar types of calculation procedure were followed for participants' tree stocks and livestock indicators. After weight calculation of each indicator, we calculated the value of each type of livelihood asset and finally the overall livelihood asset value.

\section{Results}

\subsection{Actor Power Analysis}

The study identified the actors involved in PF networks and ultimately observed who are considered to be the most powerful using the simple 1 and 2 scaling systems (Table 1). A total of 20 actors were identified in Madhupur Sal forests area who were directly or indirectly involved in PF program. In each PF networks, the individual value 2 represents the powerful actors while the actors having point 1 categorized as less or no-powerful. The results showed that the forest department in particularly the beat officer occurred the most powerful actors in all three elements (trust, incentives and coercion) of power analysis (Table 1).

Table 1 also represents that the government actors (i.e. Ministry of Forest and Environment, Madhupur National Park Management) have some sorts of power in PF networks and eventually dominated the PF programs. Other than FD, local social forestry committee has occurred power in coercion domain and in some cases the local NGOs have provide incentives to the participants.

\subsection{Livelihood Analysis}

In case of physical asset, the study was select some common indicators which were household fixed and durable assets and livestock asset. In addition, the study was select the dependency on forests for firewood uses, alternative sources of firewood uses and collective action for common infrastructure development indicators to measure the physical asset. Firewood is the main energy sources of Madhupur Sal forests as well as in whole Bangladesh and in study area, most of the firewood came from the local forests (Islam \& Sato, 2012a) area. Therefore, the study was like to see how PF programs have changed the household energy structure and whether alternative energy sources were used to sustain livelihood improvement. The results showed that the overall physical asset value was 0.77 and at the same time the value was 0.64 for non-participants (Table 2). The difference between the participants and non-participants overall physical assets showed a considerable improvements (Figure 2) of livelihood asset due to implement of PF in the study area.

Regarding to participants human asset, the study was selected the leadership indicator to judge the member's leadership ability together with other general indicators such as skill and knowledge, education and health condition. The result observed that the human asset values were 0.83 and 0.60 for participant and non-participant (Table 2). The improvement of human asset was remarkable in the study area compare to non-members values (Figure 2).

In case of natural asset, the study was select perceptions on biodiversity conservation, required activities for forest protection and conservation and member's dependency of natural forest together with member own tree stock as important indicators, and these types of indicators were also used by Chen et al. (2012) in their livelihood measurement study. The results revealed that the natural capital of the study area had positively improved (0.93) compare to non-participants (0.68) (Table 2).

To measure the social asset the study gave the highest priority on participants' relationship to the community and involve in social organizations indicators. Because of training and participation in PF programs, participants have many more opportunities to access outside information and communication with other member of the community. Overall social asset value of the participant was 0.91 which showed a substantial positive improvements in comparing with non-members' value of 0.69 (Table 2 and Figure 2).

In case of financial asset, the study argue that the household income and expenditure were treated as the two 


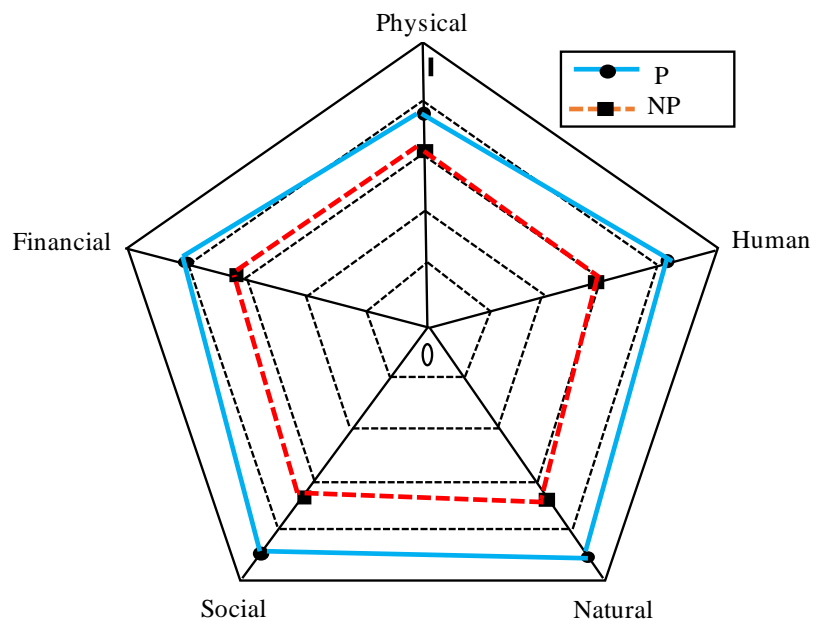

Figure 2. Overall livelihood assets pentagon.

Table 2. Evaluation of overall livelihood assets.

\begin{tabular}{|c|c|c|c|c|c|}
\hline \multirow{2}{*}{ Capitals } & \multirow{2}{*}{ Indicators } & \multicolumn{2}{|c|}{ SF participants } & \multicolumn{2}{|c|}{ Non-participants } \\
\hline & & Indicator wt. & Capital val. & Indicator wt. & Capital value. \\
\hline \multirow{5}{*}{ Human } & -Skill and knowledge due to trainings & 0.82 & & 0.46 & \multirow{5}{*}{0.60} \\
\hline & -leadership ability & 0.76 & & 0.52 & \\
\hline & -Education level/status & 0.72 & 0.83 & 0.7 & \\
\hline & -Children education status & 0.96 & & 0.72 & \\
\hline & -Health condition/status & 0.88 & & 0.62 & \\
\hline \multirow{6}{*}{ Physical } & -Household durable assets & 0.78 & \multirow{6}{*}{0.77} & 0.7 & \multirow{6}{*}{0.64} \\
\hline & -Household fixed assets & 0.72 & & 0.68 & \\
\hline & -Livestock assets & 0.76 & & 0.72 & \\
\hline & -Dependency on forests for firewood & 0.6 & & 0.46 & \\
\hline & -Alternative sources of firewood uses & 0.78 & & 0.58 & \\
\hline & -Collective action for common road structures & 0.98 & & 0.72 & \\
\hline \multirow{5}{*}{ Natural } & -Perception of biodiversity conservation & 0.96 & & 0.82 & \multirow{5}{*}{0.68} \\
\hline & -Necessary for forest protection & 0.98 & & 0.64 & \\
\hline & -Forest protection activities & 0.92 & 0.93 & 0.7 & \\
\hline & -Dependencies on natural forests & 0.86 & & 0.62 & \\
\hline & -Tree stocks & 0.92 & & 0.64 & \\
\hline \multirow{3}{*}{ Social } & -Relationship to the community & 0.96 & & 0.88 & \multirow{3}{*}{0.69} \\
\hline & -SF/training & 0.98 & 0.91 & 0.52 & \\
\hline & -Involvement in social organizations & 0.8 & & 0.68 & \\
\hline \multirow{4}{*}{ Financial } & -Total household income & 0.96 & & 0.82 & \multirow{4}{*}{0.67} \\
\hline & -SF income & 0.88 & & - & \\
\hline & -Easy loan facilities & 0.74 & 0.84 & 0.48 & \\
\hline & -Annual expenditure (\% of annual income) & 0.76 & & 0.70 & \\
\hline & Livelihood assets & \multicolumn{2}{|c|}{0.85} & \multicolumn{2}{|c|}{0.66} \\
\hline
\end{tabular}

main indicators. The main sources of household incomes were farming, day labor, working outside, small business, and collecting NTFPs (Non Timber Forest products), so, the study included all of their income as household total income indicator. For expenditure, this study considered living expenditure and production expenditure of every household and finally calculated the percent of annual expenditure in line with their total annual income. The study revealed that the overall financial asset value was 0.84 and 0.67 for the participants and non-participants (Table 2). The results also proved that participants' had significantly improved their income level compare to non-participants' (Figure 2). 


\section{Discussion}

In actor power analysis, the main focuses refer to the all identified actors and in particularly on how the powerful actors shape and accumulated their power (Maryudi, 2011). The results clearly identified that in every aspect the forest department showed the strongest preferences which is presenting in Table 2. Forest department especially the beat officer appeared the most powerful actor in trust, incentives and coercion elements of power analysis. It was due to fact that the beat officer has officially responsible for the selection of PF members, evaluation of the PF programs and benefit sharing process (Islam \& Sato, 2012a). However, the local NGOs have provided the incentives supports to the participants and the local social forestry committee was also indicated to have a certain degree of coercion of power, although the results suggested that their power appears to have been limited to only coercion elements of power. In a community forestry study of Nepal, Devkota (2011) found that forest department have gained the highest level of power in trust, incentives and coercion elements of actor power analysis. Similarly, the forest department remains one of the most powerful actor not only in coercion strategies but also provides incentives as well as being trusted in the actor dynamics analysis network of community forestry in Indonesia, Namibia, Albania, China, Philippines and Cameroon (Krott et al., 2013; Maryudi, 2011; Itubo, 2011; Devkota, 2011).

On the other, the livelihood analysis clearly showed that the PF programs indeed have a positive impact on livelihood assets improvements of participants. In case of physical assets, the dependency on natural forests for firewood indicators had greatly improved, while the participants' household fixed and durable assets had not improved a lot. The FD had supplied environmental friendly burner through a forestry project and all most all PF members received the benefit (Islam \& Sato, 2012a) at the study area. So, the adjustment of energy structure or alternative sources led to increase in indicator weight. Due to PF training, a sense of collective action had arisen among the PF members and all of those indicators showed the improvement of physical assets. In regards to human assets, the study found out that training on social forestry have had a significance impacts to the participants total income. Similarly, Islam \& Sato (2012a) and Chen et al. (2013) observed that training had significantly improved participants' capacity building towards human asset development. The natural asset indicators observed that the majority of the participants were willing to protect forests resources and biodiversity. The overall value of natural asset was significantly different between PF members and non-members. The social asset is an attribute of an individual in a social aspect (Sobel, 2002), the development of social asset depends on the relationship, institutions, attitudes and values that govern interactions among the peoples and contribute to the economic and social development and are therefore difficult to measure. In general, the PF programs have created a better social networks among the participants and other peoples' of the communities in some extent. Lastly, the financial asset of the study showed some positive increases, and a considerable differences was also detected between PF participants and non-participants. In addition, the easy loan system (such as micro credit) is well developed in Madhupur forests area. Many NGOs and private institutions are already starting micro credit facilities in Madhupur forests area, and due to their intensive activities participants can easily involve in loaning systems. All most every participants have invested their PF income to achieve their children education and family health care systems and also to cover the household expenditure that partly sustain their livelihoods.

It has already established that there is a strong link between the actors' power and livelihood development of local people in all over the world (Mariyudi, 2011). The Madhupur area's PF programs have experienced some negative impacts due to the imbalance of actors' power. The possible negative effects includes: powerful actors (e.g. FD) capture and various conflicts, creation of new form of exclusion of poor from natural resource management, parallel hierarchies of traditional leadership and unique decision making. These types of negative impacts were also mentioned by Shackleton et al. (2002); Ribot (2004); Shahbaz (2009) in their studies in different contexts. In other hand, the experiences of PF throughout the world have evident that balancing of power among PF actors' and decentralization policies often yield benefits to the local communities (Malla, 2000; Agrawal \& Gupta, 2005; Shahbaz, 2009). Although the PF in Bangladesh has outward some negative impacts due to the imbalanced power among the actors but the overall results found lot of impressive results to the development of livelihood assets of participants. Positive outcomes includes: improving relationship between FD (most powerful actor) and local communities, capacity building through intensive training, improvements of livelihood assets, increased household incomes and also government revenues, active involvement of marginal and disadvantaged groups in forest management, common roads and infrastructure development, increased awareness and perception towards forest conservation etc. So, the overall discussions argue that PF has impacted the local level and 
livelihood of the local communities have been augmented; however, the powerful actors are highly relevant for the sustainable livelihood development in Bangladesh.

\section{Conclusion}

Participatory forest management in Bangladesh has not doughtily introduced new understanding of forests with an approach to social, economic and conservation outcomes. These outcomes have depended on associated actors, their power and interest as well. The actors' power analysis of this study found out that the forest department proved itself as the most powerful and influential actors in PF. However, it is superficial to claim that through the PF programs, the forest department aspires control over the forests and other actors in recent years; the forest policy of Bangladesh and its execution have untied the opportunities to forest department. In order to change this, the forest department as well the state actors must become a facilitator to empower local level participants. Nevertheless, the PF programs have had a positive impact on the livelihood assets of the participants and all of their five livelihood assets showed increasing trends compared to non-participants. Therefore, it may say that participatory forestry has an effective management program that provided certain insights regarding the microcosm of livelihood capitals development. Finally, the study recommends that a strong commitment from important actors together with effective forest policy and management plan could make participatory forestry programs more sustainable.

\section{Acknowledgements}

The study has greatly acknowledged the Japan Society for the Promotion of Science (JSPS) for their financial support towards conducting this field study at Bangladesh and also attending the conference at Wuhan, China during 26 to 28 October 2014.

\section{References}

Agarwal, A., \& Gupta, K. (2005). Decentralization and Participation: The Governance of Common-Pool Resources in Nepal's Terai. World Development, 337, 1101-1114. http://dx.doi.org/10.1016/j.worlddev.2005.04.009

Barrow, E., Clarke, J., Grundy, I., Jones, K. R., \& Tessema, Y. (2002). Analysis of Stakeholder Based Natural Resource Management: Creating Space for Local People to Participate and Benefit? Natural Resource Perspectives (p. 320). Berkeley: University of California Press.

BBS (2006). Bangladesh Bureau of Statistics (BBS), Dhaka, Bangladesh. http://www.bbs.gov.bd/Home.aspx

Bond, A., Davis, C. N., Nott, K., \& Stuart, G. (2006). Community Based Natural Resource Manual. WWF-World Wide Fund, 24-52.

Brown, F. P. (2009). Participatory Forest Management (PFM) Discourse in South Africa: Ecological Moderation in the Developing World. Ph.D. Thesis, Durban: University of Kwa Zulu-Natal.

Carney, D. (1998). Sustainable Rural Livelihoods; What Contribution Can We Make? London: Department for International Development.

Chen, H., Zhu, T., Krott, M., Calvo, J. F., Ganesh, S. P., \& Makoto, I. (2013). Measurement and Evaluation of Livelihood Assets in Sustainable Forest Commons Governance. Land Use Policy, 30, 908-914. http://dx.doi.org/10.1016/j.landusepol.2012.06.009

Devkota, M. (2010). Interests and Power as Drivers of Community Forestry: A Case Study of Nepal. Ph.D. Thesis, Germany: University of Gottingen.

FD (Forest Department) (2014). Land and Forest Area. Official Website of Bangladesh Forest Department, Government of Forest. http://www.bforest.gov.bd/act.php

Fometer, T., \& Vermaak, J. (2001). Community Forestry and Poverty. Rural Development Forestry Network. Network Paper, Vol. 25h. Overseas Development Institute, UK, 1-8.

Hussein, K., \& Nelson, J. (1998). Sustainable Livelihood and Livelihood Diversification. IDS Working Paper, No. 69. Brighton: Institute of Development Studies.

Islam, K. K., \& Sato, N. (2012a). Participatory Forestry in Bangladesh: Has It Helped to Increase the Livelihoods of Sal Forests Dependent People. Southern Forest: A Journal of Forest Science, 74, 89-101.

Islam, K. K., \& Sato, N. (2012b). Deforestation, Land Conversion and Illegal Logging in Bangladesh: The Case of the Sal Forests. iForest: Biogeosciences and Forestry, 5, 171-178. http://dx.doi.org/10.3832/ifor0578-005 
Islam, K. K., Hoogastra, M., Ullah, M. O., \& Sato, N. (2012). Economic Contribution of Participatory Agroforestry Program to Poverty Alleviation: A Case from Sal Forests, Bangladesh. Journal of Forestry Research, 23, 323-332. http://dx.doi.org/10.1007/s11676-012-0260-6

Islam, K. K., Rahman, G. M., Fujiwara, T., \& Sato, N. (2013). People’s Participation in Forest Conservation and Livelihoods Improvements: Experience from a Forestry Project in Bangladesh. International Journal of Biodiversity Science, Ecosystem Services \& Management, 9, 30-43. http://dx.doi.org/10.1080/21513732.2012.748692

Islam, K. K., Ullah, M. O., Hoogstra, M., \& Sato, N. (2012). Economic Contribution of Participatory Agroforestry Program to Poverty Alleviation: A Case from Sal forests, Bangladesh. Journal of Forestry Research, 23, 323-332. http://dx.doi.org/10.1007/s11676-012-0260-6

Itubo, A. F. (2011). Power Dynamics within Community Forestry: Examples from Kenya. MSc Thesis, Germany: University of Gottingen.

Krott, M. (2005). Forest Policy Analysis. Dordrecht: Springer.

Krott, M., Bader, A., Schusser, C., Devkota, R., \& Maryudi, A. (2013). Actor-Centered Power: The Driving Force in Decentralized Community Based Forest Governance. Forest Policy and Economics, in press. http://dx.doi.org/10.1016/j.forpol.2013.04.012

Larson, A. M., \& Ribot, J. C. (2007). The Poverty of Forest Policy: Double Standards on an Uneven Playing Field. Sustainability Science, 2, 189-204. http://dx.doi.org/10.1007/s11625-007-0030-0

Malla, Y. B. (2000). Impact of Community Forestry Policy on Rural Livelihoods and Food Security in Nepal. http://www.fao.org/docrep/x7273e/x7273e07.htm

Maryudi, A. (2011). The Contesting Aspiration in the Forests: Actors, Interests and Power in Community Forestry in Java, Indonesia. Ph.D. Thesis, Germany: University of Gottingen.

Muhammed, N., Koike, M., Haque, F., \& Miah, M. D. (2008). Quantitative Assessment of People Oriented Forestry in Bangladesh: A Case Study from Tangail Forest Division. Journal of Environmental Management, 88, 83-92. http://dx.doi.org/10.1016/j.jenvman.2007.01.029

Peluso, N. L., Tumer, M., \& Fortman, L. (1994). Introducing Community Forestry: Annotated Listing of Tropics and Readings. Rome, FAO. http://www.fao.org/docrep/t3500e/t3500e00.htm

Ribot, J. C. (2004). Waiting for Democracy: The Politics of Choice in Natural Resource Decentralization. Washington DC: World Resource Institute.

Safa, M. S. (2004). The Effect of Participatory Forest Management on the Livelihood of the Settlers in a Rehabilitation Program of Degraded Forest in Bangladesh. Small-Scale Forest Economics, Management and Policy, 3, 223-238.

Shackleton, S., Campbell, B., Wollenberg, E., \& Edmunds, D. (2002). Devolution and Community Based Natural Resource Management: Creating Space for Local People to Participate and Benefit? Natural Resource Perspective, 76, 1-6.

Shahbaz, B. (2009). Dilemmas in Participatory Forest Management in Northwest Pakistan: A Livelihoods Perspective. Human Geography Series.

Sobel, J. (2002). Can We Trust Social Capital? Journal of Economic Literature, 40, 139-154. http://dx.doi.org/10.1257/jel.40.1.139

Webber, M. (1964). Basic Concept of Sociology. New York. 